\title{
Shale Gas Development and Property Values: Differences Across Drinking Water Sources
}

Lucija Muehlenbachs

Resources for the Future
Elisheba Spiller

Resources for the Future
Christopher Timmins

Duke University

September 2012

ERID Working Paper Number 131

This paper can be downloaded without charge from the Social Science Research Network Electronic Paper Collection: http://ssrn.com/abstract=2149612

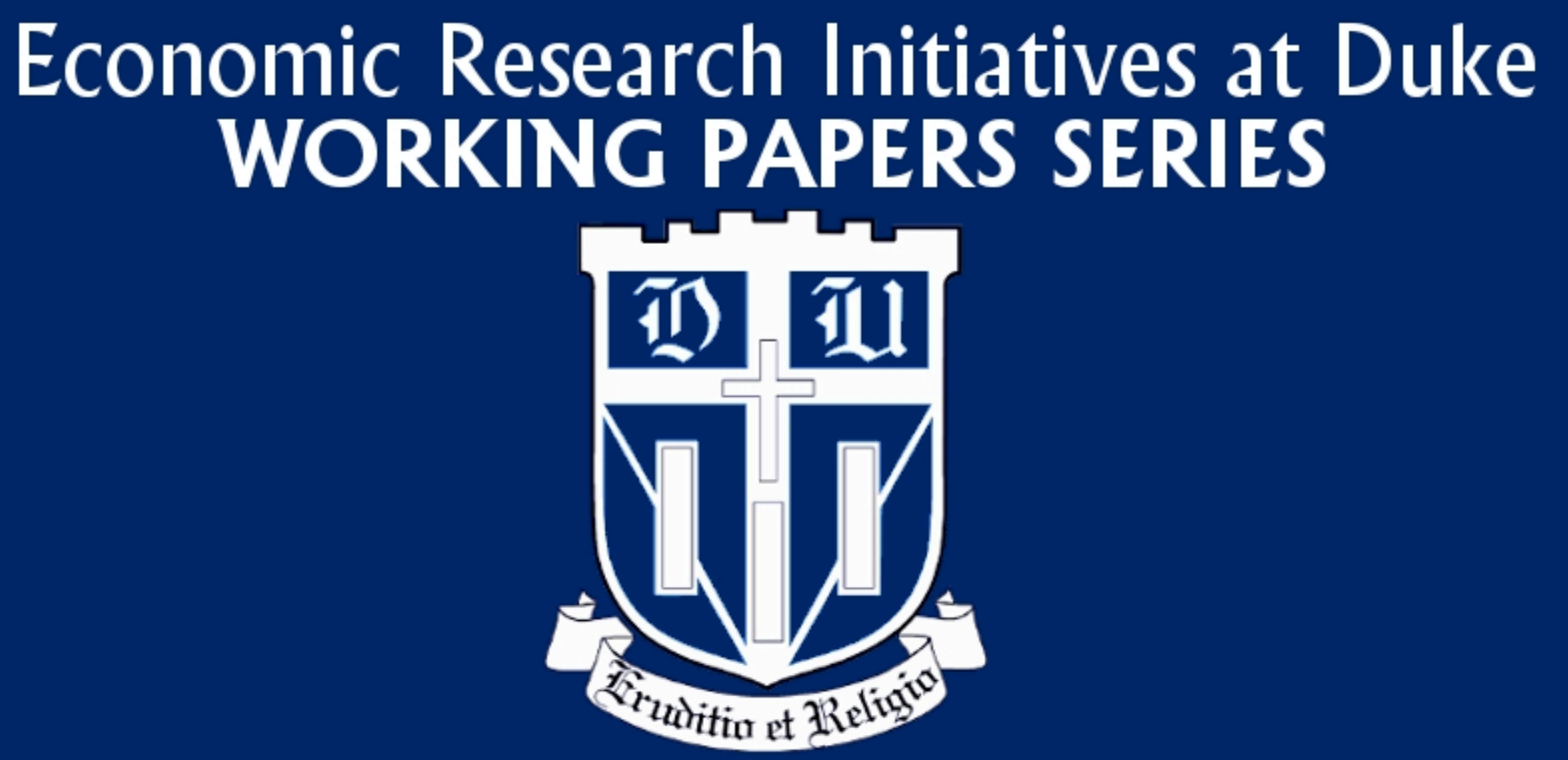




\title{
SHALE GAS DEVELOPMENT AND PROPERTY VALUES: DIFFERENCES ACROSS DRINKING WATER SOURCES
}

\author{
Lucija Muehlenbachs \\ Elisheba Spiller \\ Christopher Timmins \\ Working Paper 18390 \\ http://www.nber.org/papers/w18390
NATIONAL BUREAU OF ECONOMIC RESEARCH
1050 Massachusetts Avenue
Cambridge, MA 02138
September 2012

We thank Kelly Bishop, Jessica Chu, Carolyn Kousky, Alan Krupnick, Corey Lang, Joshua Linn, Lala Ma, Jan Mares, Ralph Mastromonaco, Stefan Staubli, Randy Walsh, and Jackie Willwerth. We thank the Bureau of Topographic and Geologic Survey in the PA Department of Conservation and Natural Resources for data on well completions. We gratefully acknowledge support from the Cynthia and George Mitchell Foundation. The views expressed herein are those of the authors and do not necessarily reflect the views of the National Bureau of Economic Research.

NBER working papers are circulated for discussion and comment purposes. They have not been peerreviewed or been subject to the review by the NBER Board of Directors that accompanies official NBER publications.

(C) 2012 by Lucija Muehlenbachs, Elisheba Spiller, and Christopher Timmins. All rights reserved. Short sections of text, not to exceed two paragraphs, may be quoted without explicit permission provided that full credit, including (C) notice, is given to the source. 
Shale Gas Development and Property Values: Differences across Drinking Water Sources Lucija Muehlenbachs, Elisheba Spiller, and Christopher Timmins

NBER Working Paper No. 18390

September 2012

JEL No. Q4,Q53

\begin{abstract}
$\underline{\text { ABSTRACT }}$
While shale gas development can result in rapid local economic development, negative externalities associated with the process may adversely affect the prices of nearby homes. We utilize a triple-difference estimator and exploit the public water service area boundary in Washington County, Pennsylvania to identify the housing capitalization of groundwater risk, differentiating it from other externalities, lease payments to homeowners, and local economic development. We find that proximity to wells increases housing values, though risks to groundwater fully offset those gains. By itself, groundwater risk reduces property values by up to 24 percent.

Lucija Muehlenbachs

Resources for the Future

1616 P Street NW

Washington DC

20036

muehlenbachs@rff.org

Elisheba Spiller

Resources for the Future

1616 P St NW

Washington DC

20036

spiller@rff.org

Christopher Timmins

Department of Economics

Duke University

209 Social Sciences Building

P.O. Box 90097

Durham, NC 27708-0097

and NBER

christopher.timmins@duke.edu
\end{abstract}




\section{Introduction}

A recent increase in the extraction of natural gas and oil using unconventional methods has transformed communities and landscapes. This paper focuses on shale gas extraction in Pennsylvania, which has grown rapidly in recent years thanks to developments in hydraulic fracturing and horizontal drilling. Natural gas provides an attractive source of energy. When burned, it emits fewer pollutants (e.g., carbon dioxide, sulfur dioxide, nitrogen oxides, carbon monoxide and particulate matter) than other fossil-fuel energy sources per unit of heat produced, and it comes from reliable domestic sources. The extraction of natural gas from shale, that had hitherto been economically unrecoverable, has resulted in greatly expanded supply and in many landowners receiving high resource rents for the hydrocarbons beneath their land. There are, however, many potential risks that accompany the drilling and hydraulic fracturing process. The processes required to develop and produce natural gas from shale rock use a great deal of water and require the injection of chemicals deep into the ground at high pressure. Compared with conventional natural gas development, this may result in greater risk to air, water, and health. Important for housing markets and local tax revenues, the environmental impact of shale gas development and the perception of the risks associated with these processes, as well as increased truck traffic or the visual burden of a well pad, could depress property values. ${ }^{1}$

The risks associated with leasing one's land to gas exploration and production companies are especially important for homes that depend on groundwater as a source of drinking water. One of the most often discussed risks associated with shale gas development is the potential for groundwater contamination. Faulty well casings or cement could provide a pathway for contaminants to reach a drinking water aquifer [SEAB, 2011, Osborn et al., 2011]. Another arises if hydraulic fracturing occurs too close to a drinking water aquifer [EPA, 2011] or if there are naturally occurring hydraulic pathways between the formation and the drinking water aquifer [Warner et al., 2012, Myers, 2012]. Even if shale gas operations do not contaminate groundwater in the short run, the possibility of future groundwater contamination may be capitalized negatively into the property

\footnotetext{
${ }^{1}$ The potential for reduction of property values is important given the current housing crisis, as, in severe cases, it could cause homeowners to fall "under water" in terms of mortgage repayment, potentially increasing the risk of loan default and foreclosure.
} 
value, resulting in important long-term consequences for the homeowner.

However, there is also evidence that natural gas development creates jobs and generates income for local residents [Weber, 2011, Marchand, 2011]. Upon signing their mineral rights to a gas company, landowners may receive two dollars to thousands of dollars per acre as an upfront "bonus" payment, and then a 12.5 percent to 21 percent royalty per unit of gas extracted. ${ }^{2}$

Although it is likely that property values will be affected by shale gas well proximity (both positively and negatively), there has been little research into how the presence of a natural gas well affects property values overall. ${ }^{3}$ In this paper, we use a triple-difference, or difference-in-difference-in-differences (DDD) estimator, applied to properties that border the public water service area (PWSA), to measure the effect of groundwater water contamination concerns from shale gas development. Understanding both the positive and negative impacts of shale gas exploration can help the government make decisions (such as implementing increased regulation to ensure groundwater integrity or extending the reach of the PWSA) that could protect homeowners from the negative effects of shale gas development while allowing for the benefits associated with increased local economic growth, lease payments, and a cleaner source of fossil-fuel energy. State regulators are currently debating such rules and regulations. In this paper we estimate the differential effect of shale gas development on properties that depend on groundwater and those that have access to piped water, giving us valuable insights into the capitalization of groundwater contamination risk. ${ }^{4}$

The key to estimating the concern for groundwater contamination is controlling for correlated unobservables that may bias estimates (e.g., unattractive attributes of properties and neighborhoods that may be correlated with exposure to drilling activity, and beneficial factors like lease payments and increased economic development). Even in the best data sets, these factors may be hard to measure, and can lead to omitted variables bias.

We take several steps to overcome this bias. The intuition proceeds as follows. First, we use property fixed effects, comparing changes in the price of a

\footnotetext{
${ }^{2}$ Natural Gas Forum for Landowners: Natural Gas Lease Offer Tracker, Available on: http://www.naturalgasforums.com/natgasSubs/naturalGasLeaseOfferTracker.php.

${ }^{3}$ Two notable exceptions are Boxall et al. [2005], Klaiber and Gopalakrishnan [2012].

${ }^{4}$ Even if groundwater in Pennsylvania had been contaminated prior to drilling [Swistock et al., 1993], our estimation strategy deals with this concern by using information on sales of the same property before and after drilling.
} 
particular property over time, controlling non-parametrically for anything about that property that remains the same. Next, we see how those price changes differ depending upon whether the property is located in a treatment or control area, defined according to well proximity. Finally, we observe how the differences in the change in price across proximity-based treatment and control groups differ depending upon water source (i.e., groundwater versus piped water). In addition to controlling for any time-invariant unobserved heterogeneity at the level of the property, our approach will also control for two sources of potential time-varying unobservable heterogeneity - (i) anything common to our proximity-based treatment and control groups (e.g., lease payments); and (ii) anything within one of those groups that is common to both groundwater and PWSA households (e.g., increased local economic activity). Furthermore, we also geographically restrict some of the specifications in our analysis to the smallest available neighborhood that will allow us to observe differences in water source: a 1000 meter buffer drawn on both sides of the PWSA boundary. This reduces the burden on our differencing strategy to control for time varying unobservables, as homes located within a few blocks of each other presumably are affected similarly by these time varying unobservables. Using this identification strategy along with data on property sales in Washington County, Pennsylvania, from 2004 to 2009, we find that properties are positively affected by the drilling of a shale gas well unless the property depends on groundwater.

\section{Application of the Hedonic Model for Non- Market Valuation}

In the hedonic model (formalized by Rosen [1974]), the price of a differentiated product is a function of its attributes. In a market that offers a choice from amongst a continuous array of attributes, the marginal rate of substitution between the attribute level and the numeraire good (i.e., the willingness to pay for that attribute) is equal to the attribute's implicit (hedonic) price. The slope of the hedonic price function with respect to the attribute at the level of the attribute chosen by the individual is therefore equal to the individual's marginal willingness-to-pay for the attribute; thus, the hedonic price function is the envelope of the bid functions of all individuals in the market. This implies that 
we can estimate the average willingness-to-pay for an attribute (i.e., exposure to groundwater risk from hydraulic fracturing) by looking at how the price of the product (i.e., housing) varies with that attribute.

A vast body of research has examined the housing price effects of locally undesirable land uses, such as hog operations [Palmquist et al., 1997], underground storage tanks [Guignet, 2012], and power plants [Davis, 2011] to name a few. These estimates are then used to measure the disamenity value of the land use (or willingness-to-pay to avoid it). This paper similarly uses hedonic methods to model the effect of proximity to a shale gas well on property values. ${ }^{5}$ In particular, we use variation in the market price of housing with respect to changes in the proximity of shale gas operations to measure the implicit value of a shale well to nearby home owners, depending upon water source. As such, it should be able to pick-up the direct effect of environmental risks - in particular, risk of water contamination and consequences of spills and other accidents - while differentiating those risks from other negative externalities (e.g., noise, lights, and increased truck traffic) and the beneficial effects of increased economic activity and lease payments. The latter is analogous to the effect of a wind turbine [Heintzelman and Tuttle, 2012], where the undesirable land use is also accompanied by a payment to the property on which it is located. In this paper, we focus on the hedonic impact of groundwater contamination risk on property values, as it is generally considered to be one of the most significant risks from shale gas development. ${ }^{6}$

The academic literature describing the costs of proximity to oil and gas drilling operations is small. See, for example, Boxall et al. [2005], which examines the property value impacts of exposure to sour gas wells and flaring oil batteries in Central Alberta, Canada. The authors find significant evidence of substantial (i.e., 3-4 percent) reductions in property values associated with proximity to a well. Klaiber and Gopalakrishnan [2012] also examine the effect of shale gas wells in Washington County, using data from 2008 to 2010. They examine the temporal dimension of capitalization due to exposure to wells, focusing on sales during a

\footnotetext{
${ }^{5}$ Assuming that the housing supply is fixed in the short-run, any addition of a shale gas well is assumed to be completely capitalized into price and not in the quantity of housing supplied. Given that the advent of shale gas drilling is relatively recent, we would expect to still be in the "short-run". As more time passes, researchers will be able to study whether shale gas development has had a discernable impact on new development.

${ }^{6}$ Krupnick et al, "What the Experts Say About Shale Gas: There's More Consensus Than You Think," RFF Discussion Paper, Forthcoming.
} 
short window (e.g., 6 months) after well permitting and using school district fixed effects to control for unobserved heterogeneity. Like Boxall et al. [2005], Klaiber and Gopalakrishnan [2012] also find that wells have a small negative impact on property values. We find evidence of much larger effects on property values a difference we ascribe to the rich set of controls for unobservables (both timeinvariant and time-varying) used in our DDD identification strategy described above.

Because the hedonic price function is the envelope of individual bid functions, it will depend upon the distributions of characteristics of both home buyers and the housing stock. This means that if few of the neighborhoods in our sample are affected by increased traffic and noise, then there will be a lower premium placed on quiet neighborhood location. However, if shale development is widespread and results in most neighborhoods being affected by heavy truck traffic, then the houses located in the relatively few quiet neighborhoods would receive a high premium. In the case of a widespread change in the distribution of a particular attribute in the housing stock, it is possible that the entire hedonic price function might change, so that even the price of properties far from shale wells will be affected. Furthermore, the hedonic price function is dependent on the distribution of tastes. If the mix of homebuyer attributes changes dramatically over time, that could also lead to a shift in the hedonic price function. Bartik [1988] shows that, if there is a discrete, non-marginal, change that affects a large area, the hedonic price function may shift, which can hinder one's ability to interpret hedonic estimates as measures of willingness to pay. Rather, the estimates may simply describe capitalization effects [Kuminoff and Pope, 2012]. This would be a conservative interpretation of our results. Whereas a willingness to pay interpretation is useful for the cost-benefit analysis of alternative regulations and standards that might be imposed on drillers, a focus on the capitalization effect is relevant for policy if we are interested in whether shale gas wells increase the risk of mortgage default. It is also important for local fiscal policy, as drilling may have important implications for property tax revenues. 


\section{Background on Risks Associated with Shale Gas Development}

Shale gas extraction has become viable because of advances in hydraulic fracturing and horizontal drilling. Hydraulic fracturing is a process in which large quantities of fracturing fluids (water, combined with chemical additives including friction reducers, surfactants, gelling agents, scale inhibitors, anti-bacterial agents, and clay stabilizers and proppants) are injected at high pressure so as to fracture and prop open the shale rock, allowing for the flow of natural gas contained therein. The multiple risks associated with fracking (including the contamination of groundwater) may have an impact on property values and are, hence, relevant for mortgage lenders. ${ }^{7}$ Knowing the perceived costs associated with these risks can also be of use to regulators considering different standards for drilling operations.

First, development can cause contamination of local water supply resulting from improper storage, treatment, and disposal of wastewater. Hydraulic fracturing also generates "flowback fluid" and produced water, the hydraulic fracturing fluids and formation water that return to the surface, often containing salts, metals, radionuclides, oil, grease, and VOC's. These fluids might be recycled for repeated use at considerable cost, treated at public or private waste water treatment facilities, or injected in deep underground injection wells. Mismanagement of flowback fluid can result in contamination of nearby ground and surface water supplies. Second, air pollution is a concern - escaped gases can include NOx and VOC's (which combine to produce ozone), other hazardous air pollutants (HAP's), methane and other greenhouse gases. Third, spills and other accidents can occur - unexpected pockets of high pressure gas can lead to blowouts that are accompanied by large releases of gas or polluted water, and improper wellcasings can allow contaminants to leak into nearby groundwater sources. Fourth, there may also be a risk of contamination from drill cuttings and mud. These substances are used to lubricate drill bits and to carry cuttings to the surface and often contain diesel, mineral oils or other synthetic alternatives, heavy metals (e.g., barium) and acids. These materials can leach into nearby groundwater

\footnotetext{
${ }^{7}$ For a risk matrix for shale gas development see: http://www.rff.org/centers/energy_economics_and_policy/Pages/Shale-Matricies.aspx.
} 
sources. Other negative externalities include noise, increased traffic, deterioration of roads due to heavy truck traffic, minor earthquakes, and clearing of land to drill wells, which can also affect property values by reducing the aesthetic appeal of the region in general.

\section{Method}

Implementation of the hedonic method is complicated by the presence of property and neighborhood attributes that are unobserved by the researcher but correlated with the attribute of interest. The specifications we use in order to demonstrate and address this problem include a simple cross-section, a property fixed effects regression, and a triple-difference (DDD) estimator that uses detailed geographical information about well proximity and the placement of the piped water network to define several overlapping treatment and control groups. We briefly review the econometric theory behind each of these approaches below.

\subsection{Cross-Sectional Estimates}

The most naïve specification ignores any panel variation in the data and simply estimates the effect of exposure to a shale gas well by comparing the prices of properties in the vicinity of a well to those properties not exposed to a well. Considering the set of all houses in the study area, we run the following regression specification:

$$
P_{i}=\beta_{0}+\beta_{1} W E L L D I S T_{i}+X_{i}^{\prime} \delta+Y E A R_{i}^{\prime} \gamma+\varepsilon_{i}
$$

where

$P_{i} \quad$ natural $\log$ of transaction price of property $i$

$W E L L D I S T_{i}$ distance to nearest shale gas well at the time of transaction

$X_{i} \quad$ vector of attributes of property $i$

$Y E A R_{i} \quad$ vector of dummy variables indicating year property $i$ is sold

In this specification, the effect of exposure to a well is measured by $\beta_{1}$.

The problem here is that $W E L L D I S T_{i}$ is likely to be correlated with $\varepsilon_{i}$ (i.e., 
properties and neighborhoods that are near wells are likely to be different from those that are not near wells in unobservable ways that may also affect property values). For example, houses located in close proximity to wells may be of lower or better quality than those located elsewhere in the county. One way to check for this possibility is by comparing observable attributes of properties and neighborhoods, both located near and far from shale gas wells. Significant differences in observable attributes suggests a potential for differences in unobservables, which could lead to bias in the estimation of Equation (1) (see Table 5 in the Appendix). Therefore, it is important to control for these unobserved location attributes that lead to the location decisions by gas exploration and production companies.

Utilizing pooled ordinary least squares (OLS) can also be problematic since the error terms associated with homes sold multiple times will likely be correlated, given that unobserved attributes of the home may not change much over time. This creates correlation between the error terms, which violates the assumption of i.i.d. error terms necessary for consistent estimation of the parameters. Using property fixed effects allows us to control for these correlated unobservables by specifically accounting for the correlation within homes sold more than once.

\subsection{Property Fixed Effects}

Properties that are near shale wells might differ systematically in unobservable ways from those that are not near wells. If properties farther from wells are associated with more desirable unobserved characteristics, then this would create an elevated baseline to which the properties near wells would be compared, inflating the estimated negative effect of proximity to a well. Utilizing property-level fixed effects allows us to difference away the unobservable attributes associated with a particular property, or with the property's location.

In our second specification, we exploit the variation in panel data to control for time-invariant property attributes with property-level fixed effects. Suppose $P_{i t}$ measures the natural $\log$ of the price of property $i$, which transacts in year $t$. $X_{i}$ is a vector of attributes of the property ${ }^{8}$, and $W E L L D I S T_{i t}$ is the distance of property $i$ to the nearest well at the time of the transaction. $\mu_{i}$ is a time-invariant attribute associated with the property that may or may not be observable by the

\footnotetext{
${ }^{8}$ The property attributes do not change over time in our dataset, because the attributes of the property in the final transaction are the only attributes that are recorded in the data.
} 
researcher, and $\nu_{i t}$ is a time-varying unobservable attribute associated with the property. Importantly, $\mu_{i}$ may be correlated with $W E L L D I S T_{i t}$ in the following equation:

$$
P_{i, t}=\beta_{0}+\beta_{1} W E L L D I S T_{i t}+X_{i}^{\prime} \delta+\mu_{i}+\nu_{i t}
$$

We employ a fixed effects technique in order to remove $\mu_{i}$ from Equation 2:

$$
\tilde{P}_{i t}=\beta_{1} W E \widetilde{E L D} I S T_{i t}+\tilde{X}_{i}^{\prime} \delta+\tilde{\nu}_{i t}
$$

where $\tilde{P}_{i t}, W E \widetilde{L L D} I S T_{i t}, \tilde{X}_{i}$, and $\tilde{\nu}_{i t}$ are mean differenced variables. Estimating this specification controls for any permanent unobservable differences between properties that have the shale well treatment and those that do not.

\subsection{Difference-in-Difference-in-Differences (DDD)}

While property-level fixed effects account for time-invariant unobserved property and location attributes, they are not able to control for time-varying sources of unobservable heterogeneity. This is a concern, as shale gas production could be associated with a boom to the local economy and with valuable payments for mineral rights at the property level, both of which can be hard to quantify, yet may be correlated with well proximity. As Table 1 demonstrates, average distance to the nearest well decreases over time as more wells are drilled. In fact, the average distance to a well decreased by almost 50 percent over the time period. If the economic boom associated with increased in-migration and employment due to drilling activity increases property values over time, then this increased capitalization will appear to be caused by closer proximity to shale gas wells. If we do not take this underlying trend into account, then we will underestimate the negative impact of the well. Failure to account for payments for mineral rights can have a similar effect. This warrants going beyond a simple fixed effects specification and conducting a quasi-experimental procedure that removes the underlying time trends and better estimates the impact of proximity to shale gas wells on property values. We employ a linear DDD technique, which is described in more detail below. There, we define a pair of overlapping treatment and control groups of properties by exploiting a property's proximity to wells and whether or not it is part of the public water service area (PWSA). 
Table 1: Shale Gas Activity Over Time in Washington County, PA

\begin{tabular}{ccccc}
\hline \hline Year & No. Wells & No. Permitted & Dist. To Nearest Well $(\mathrm{m})$ & Dist. to Nearest Permit $(\mathrm{m})$ \\
\hline 2005 & 5 & 9 & $11,952.9$ & $11,952.9$ \\
2006 & 25 & 32 & $11,879.4$ & $11,883.6$ \\
2007 & 80 & 116 & $9,370.8$ & $7,806.5$ \\
2008 & 188 & 221 & $7,336.6$ & $7,329.3$ \\
2009 & 188 & 268 & $6,326.3$ & $6,323.6$ \\
\hline \hline
\end{tabular}

Notes: Counts are of wellpads (there may be multiple wellbores on each wellpad).

\subsubsection{Treatment Group Well Proximity}

In order to identify the properties "treated" by exposure to groundwater contamination risk, we first exploit the fact that the effects of a well are localized, in that many of the disamenities associated with development (such as noise and truck traffic along with groundwater contamination) will not affect properties farther from a well. At some distance far enough away from the well site, drilling may not influence property values at all. This appears to be the case based on work by Boxall et al. [2005] on sour gas wells in Alberta, Canada. In order to identify the correct treatment distance from a well, we conduct an econometric test to see at which point the well no longer impacts property values. The test we employ follows the strategy of Linden and Rockoff [2008]. This method compares properties sold after a well has been drilled (within certain distances) to properties sold prior to a well being drilled (within the same distance), and identifies at which distance wells stop impacting property values. We then define our first treatment group as properties having a well within this distance. 


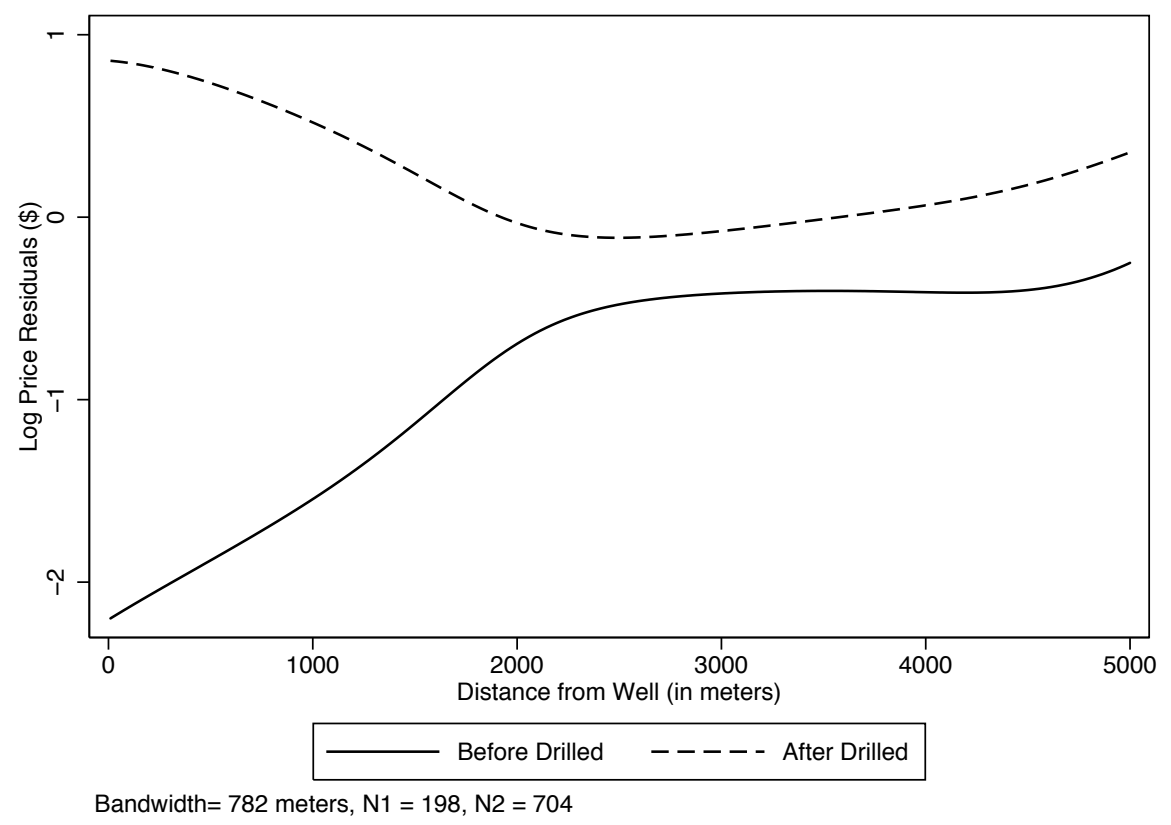

Figure 1: Sales Price Gradient of From Local Polynomial Regressions on Distance from Current/Future Well

In order to conduct the Linden and Rockoff [2008] test, we create a subsample of properties that have, at some point in time (either before the property is sold or after), only one well pad located within 5000 meters. We begin by estimating two price gradients based on distance to a well: one for property sales that occurred prior to a well being drilled and one for property sales after drilling began. The distance at which the difference in these two price gradients becomes insignificant is the distance at which we can define the first treatment group. Figure 1 shows these price gradients estimated by local polynomial regressions. For properties that are located more than 2000 meters from a well, the gradients are similar both before and after the well is drilled. However properties located closer than 2000 meters to a well are sold for more on average after the well is drilled than before the well is drilled, which would correspond to properties receiving, or expecting to receive, lease payments. ${ }^{9}$ The solid line in the graph demonstrates that properties sold prior to a well being drilled within 2000 meters receive lower sale prices the closer they are to a well, implying that wells are being located in areas with

\footnotetext{
${ }^{9}$ A horizontal well might extend over a mile (1609 meters) and therefore it is possible for a property within 2000 meters of a well to be receiving payments.
} 
negative unobservable attributes. ${ }^{10}$ Thus, we use a distance of 2000 meters from a well to measure the treatment, where any property located farther than 2000 meters is assumed to not be affected by well drilling. Importantly, we expect the effects of a boom to the local economy to be similar across that 2000 meter threshold. This defines our first treatment-control group: treated homes are those located within 2000 meters distance of a shale gas well, and the control homes are those located outside this 2000 meters band. This allows us to control for the unobserved time varying factors that are correlated with shale gas development by looking at homes sold inside and outside of a 2000 meter boundary of shale gas wells, as both these groups will likely be affected in similar ways by a regional economic boom. Finally, given evidence that wells are located in less desirable areas, we control for these unobserved area attributes with property fixed effects.

\subsubsection{Private Water Wells vs. Piped Water}

Much of the concern surrounding shale gas development arises from the risk of groundwater contamination. Properties that utilize water wells may be affected if the surface casing of a gas well cracks and methane or other contaminants migrate into the groundwater [SEAB, 2011, Osborn et al., 2011] or if fractures connecting the shale formation reach the aquifer [Warner et al., 2012, Myers, 2012]. Properties that receive drinking water from water service utilities, on the other hand, do not face this risk. ${ }^{11}$ We hypothesize that this risk may be capitalized into the value of the property; in particular, households using water wells may be more adversely affected by proximity to shale gas wells relative to households relying on piped water, and therefore would face a lower transaction value when "treated" by proximity to a well. In order to capture this difference across properties, we define an additional treatment group by designating properties depending upon whether they rely on groundwater or piped water. Specifically, we use GIS data on the location of the PWSA and map the properties into their respective groups.

\footnotetext{
${ }^{10}$ Creating this figure after excluding properties that have permitted, but not drilled, wells nearby excludes only 11 observations and results in a figure similar to Figure 1 . This provides further evidence that the upward sloping portion of the "before drilled" line reflects negative unobservables correlated with proximity rather than expectations of future drilling.

${ }^{11}$ While hydraulic fracturing may cause contamination of the publicly available water supply, the city is tasked with providing clean water to its constituents, so the risk of receiving contaminated water through piped water lines is much lower than an unregulated well managed by a homeowner.
} 
This allows us to interact distance with a groundwater indicator in our estimation in order to find the different impact of proximity to wells for groundwater versus piped water homes. Any differences between groundwater and piped water dependent properties that were present before the well is put in place are accounted for at a very detailed level by property fixed effects. While properties within 2000 meters of a shale gas well are equally likely to receive benefits from lease payments regardless of water source, those properties dependent upon groundwater are more likely to capitalize the negative consequences of increased contamination risk. This defines our second treatment-control group: by looking at the difference across groundwater dependence (and within 2000 meters of a shale gas well), we are essentially controlling for the unobserved lease payments that are common to both these groups, while allowing the first treatment effect (proximity to shale gas wells) to vary by drinking water source.

As a preliminary examination of whether and how groundwater and PWSA homes differ in their impact from shale gas well proximity, we conduct a generalized propensity score (GPS) model, as detailed in Hirano and Imbens [2004]. GPS allows the treatment of proximity to vary continuously, while regular matching models assume a binary treatment. For this test, we thus define the treatment as the distance to the nearest well, and estimate the impact on property values as this distance is varied. We include as controls property characteristics and census tract attributes. ${ }^{12}$ Figure 2 demonstrates the impact of proximity to shale gas wells for the entire sample (including cities), and it appears that the treatment effect of proximity varies substantially with water service. For properties in a PWSA, being close to a shale gas well actually increases property values. This implies that the local economic development and lease payments associated with shale development can boost the housing market substantially, but only if the property is protected in some way from the environmental impacts. However, for properties without piped water, being closer to a shale gas well decreases property values. Thus, we find strong evidence of a contrasting impact across different water service areas. Figure 2 also shows that the impact of proximity to shale wells tapers off after approximately $6 \mathrm{~km}$, providing evidence that the impact of

\footnotetext{
${ }^{12}$ Ideally, we would run the estimation on each year separately in order to eliminate the time-varying issues that can bias the outcome from the fixed effects model. Unfortunately, our sample size is not large enough to run it with each year separately, so we have to estimate the dose response aggregated from 2006-2009. However, to control for the unobserved attributes correlated with years, we include year dummies.
} 
shale development are localized.

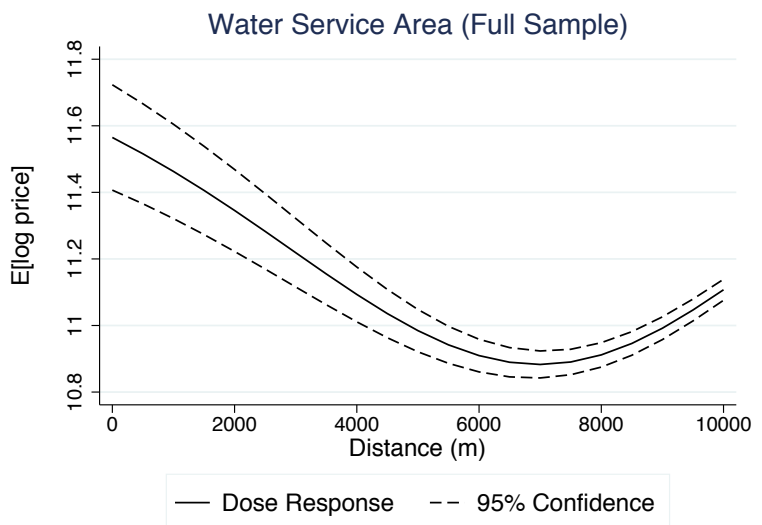

(a)

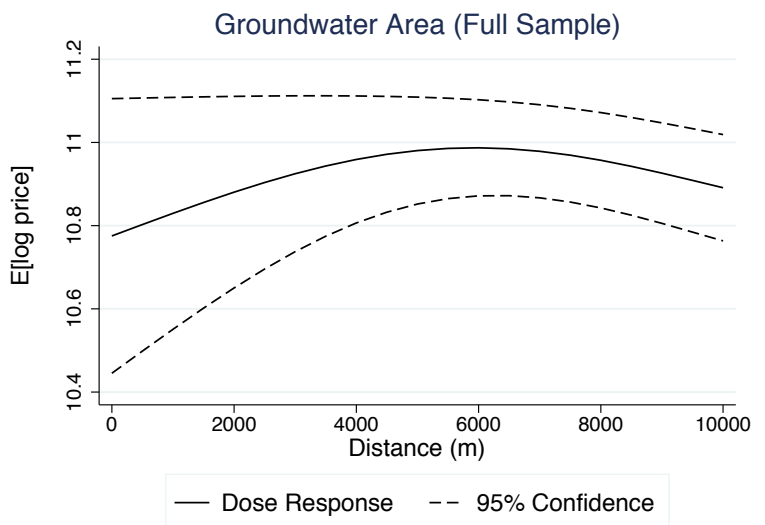

(b)

Figure 2: Impact on Property Values from Proximity to the Nearest Shale Gas Well

\section{Data}

Our main dataset is used under an agreement between the Duke University Department of Economics and Dataquick Information Services, a national real estate data company. These property data include information on all properties sold in Washington County, Pennsylvania from 2004 to 2009. The buyers' and sellers' names are provided, along with the transaction price, exact street address, square footage, year built, lot size, number of rooms, number of bathrooms, number of units in building, and many other characteristics. We begin with 41,266 observations in Washington County, PA, and remove observations that do not list a transaction price, have a zero transaction price, ${ }^{13}$ do not have a latitude/longitude coordinate, were sold prior to a "major improvement", ${ }^{14}$ are described as only a land sale (a transaction without a house), or claim to be a zero square footage house. The final cleaned dataset has 19,055 observations. Summary statistics

\footnotetext{
${ }^{13}$ Most observations are removed after deleting transactions with a price of zero $(12,327$ observations).

${ }^{14}$ We delete sales prior to major improvements because Dataquick data only report property characteristics at the time of the last recorded sale. If the property was altered between the last sale and earlier sales, we would have no record of how it had changed. Nonetheless this only removes 4 observations.
} 
comparing the full sample and final sample show that they are similar in all respects except the transaction price (Table 2) - that difference being attributable to dropping observations with a zero price.

Table 2: Summary Statistics

\begin{tabular}{|c|c|c|c|c|}
\hline & \multicolumn{2}{|c|}{ Final Sample } & \multicolumn{2}{|c|}{ Full Sample } \\
\hline & Mean & Std. Dev. & Mean & Std. Dev. \\
\hline \multicolumn{5}{|l|}{ Property Characteristics: } \\
\hline Transaction Price (Dollars) & 127,233 & 135,002 & 103,462 & 181,573 \\
\hline Ground Water & 0.09 & 0.286 & 0.1 & 0.3 \\
\hline Age & 54.6 & 39.7 & 52.6 & 40 \\
\hline Total Living Area (1000 sqft) & 1.8 & 0.877 & 1.79 & 0.88 \\
\hline No. Bathrooms & 1.69 & 1.01 & 1.66 & 1.02 \\
\hline No. Bedrooms & 2.73 & 1.12 & 2.65 & 1.15 \\
\hline Sold in Year Built & 0.118 & 0.322 & 0.0954 & 0.294 \\
\hline Lot Size $(100,000$ sqft $)$ & 0.244 & 0.766 & 0.262 & 1.3 \\
\hline Distance to Nearest MSA $(\mathrm{km})$ & 35.8 & 7.04 & 35.8 & 7.1 \\
\hline \multicolumn{5}{|l|}{ Census Tract Characteristics: } \\
\hline Mean Income & 65,655 & 23,778 & 66,132 & 23,474 \\
\hline \% Under 19 Years Old & 23.9 & 4.19 & 23.8 & 4.14 \\
\hline$\%$ Black & 3.78 & 5.87 & 3.61 & 5.74 \\
\hline$\%$ Hispanic & 0.426 & 0.72 & 0.428 & 0.713 \\
\hline$\%$ Age $25 \mathrm{w} /$ High School & 39.2 & 10.5 & 39.2 & 10.4 \\
\hline$\%$ Age 25 w Bachelors & 16.7 & 7.51 & 16.9 & 7.51 \\
\hline \% Same House 1 Year & 88.6 & 6.75 & 88.8 & 6.64 \\
\hline$\%$ Unemployed & 6.19 & 2.84 & 6.11 & 2.82 \\
\hline$\%$ Poverty & 7.63 & 6.93 & 7.38 & 6.86 \\
\hline$\%$ Public Assistance & 2.21 & 2.13 & 2.11 & 2.1 \\
\hline$\%$ Over 65 Years Old & 17.7 & 4.92 & 17.8 & 4.89 \\
\hline \% Female Household Head & 10 & 5.6 & 9.85 & 5.54 \\
\hline \multicolumn{5}{|l|}{ Shale Well Proximity: } \\
\hline Distance to Closest Well (m) & 10,109 & 4,307 & & \\
\hline Distance to Closest Permit (not Drilled) (m) & 10,239 & 4,675 & & \\
\hline Number of Wellpads Drilled within $2 \mathrm{~km}$ & .0306 & .489 & & \\
\hline Observations & 19,055 & & 26,236 & \\
\hline
\end{tabular}

Notes: Transactions in Washington County, 2004-2009, of houses in sub-sample used, and all transactions. The number of observations varies depending

In order to control for neighborhood amenities, we match each property's location with census tract information, including demographics and other characteristics. The census tract data come from the American Community Survey, which provides a tract-level moving average of observations recorded between the years 2005 and 2009 .

We also match geocoded property transactions data to our second main data source - the location of wells in Washington County. We obtained data describing the permitted wells located on the Marcellus shale from the Pennsylvania Department of Environmental Protection. To determine whether the permit has been drilled, we rely on two different datasets. A well is classified as drilled if there was a "spud" date (i.e., date that drilling commenced) listed in the Pennsylvania 


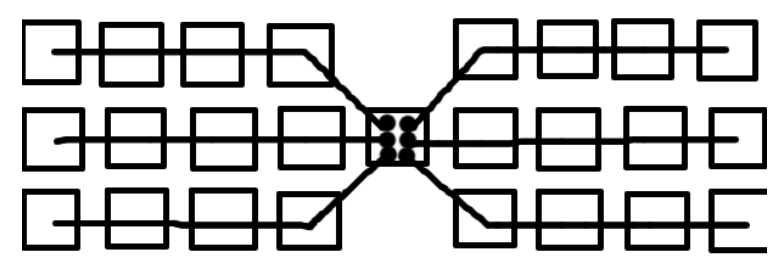

Figure 3: Well Pad with Multiple Wells

Department of Environmental Protection Spud Data or if there was a completion date listed in the Department of Conservation and Natural Resources Well Information System (The Pennsylvania Internet Record Imaging System/Wells Information System [PA*IRIS/WIS]). As there were many wells listed in one but not both datasets, combining the two datasets provides us with a more complete picture of drilling activity in this part of Pennsylvania. The final dataset includes both vertical and horizontal wells, both of which produce similar disamenities, including risks of groundwater contamination. ${ }^{15}$

Many of these wells are in very close proximity to one another, yet the data do not identify whether these wells are on the same well pad. Well pads are areas where multiple wells are placed close to each other, allowing the gas companies to expand greatly the area of coverage while minimizing surface disturbance. As current shale gas extraction in Pennsylvania typically involves horizontal drilling, a well pad can include many wells in close proximity while maximizing access to shale gas below the surface. Figure 3 demonstrates how six horizontal wells can be placed on a small well pad, minimizing the footprint relative to vertical drilling (which would require 24 wells evenly spaced apart, as indicated by the squares in the figure).

Without identifying well pads, we might overstate the extent of drilling activity confronting a property. For example, a property near the well pad in Figure 2 would be identified as being treated by six wells, though presumably after the first well has been drilled, the additional impact from each additional wellbore would be less than the first. Thus, we create well pads using the distance between

\footnotetext{
${ }^{15}$ Risk of improper well casing or cementing would be present in both vertical and horizontal wells.
} 
the wells, and treat each well pad as a single entity. In order to create well pads, we choose all wellbores that are within one acre (a 63 meter distance) of another wellbore and assign them to the same well pad. ${ }^{16}$ In our data, of the wellbores that are within one acre of another wellbore, 50 percent are within 11 meters and 75 percent are within 20 meters. Any wellbore within one acre is considered to be on the same well pad, so if more than two wellbores are included, our constructed well pads can cover an area larger than one acre. The average number of wellbores per well pad is 3.7 ( $\max$ of 12 ), where 25 percent of the well pads in our data have only 1 well.

We begin by matching property transactions to all wells located within $20 \mathrm{~km}$ of the property, including permitted but not drilled wells, drilled wells, and prepermitted wells (i.e., wells that are permitted and drilled after the time of the property transaction). Once these wells are matched, we create variables that measure each house's Euclidean distance to the closest well pad that is either permitted or drilled at the time of the transaction, and variables describing the well count within 2000 meters. These are our main variables of interest, as they identify our "treatment": how proximity to wells affects property values. We also calculate the inverse of the distance to the nearest well and use this variable as the treatment in the cross sectional and fixed effects specifications, allowing for an easier interpretation of the results - an increase in inverse distance implies a closer distance to a well, so a positive coefficient would imply a positive valuation of proximity. Furthermore, utilizing inverse distance places more emphasis on homes that are closer to wells; this is a reasonable functional form (relative to a linearly decreasing function), given that the marginal disutility of disamenities associated with drilling likely declines as one moves further from a well (i.e., visual aesthetic issues may not be present at 3-4 miles distance, though truck traffic may still affect those farther away).

In order to capture the water contamination risks that home owners may face from shale gas extraction, we utilize data on public water service areas in Washington County and identify properties that do not have access to public piped drinking water. We obtained the GIS boundaries of the public water supplier's service area from the Pennsylvania Department of Environmental Protection.

\footnotetext{
${ }^{16}$ During completion, a multi-well pad, access road, and infrastructure are estimated to encompass 7.4 acres in size, after completion and partial reclamation, a multi-well pad averages 4.5 acres in size [New York State Department of Environmental Conservation, 2011].
} 
Properties located outside of a PWSA most likely utilize private water wells, since the county does not provide much financial assistance to individuals who wish to extend the piped water area to their location. ${ }^{17}$ This allows us to separate the analysis by water service area into PWSA and "groundwater" areas, and we use this distinction to identify the water contamination risk that may be capitalized into the transaction value. Figure 4 shows the map of Washington County, Pennsylvania, describing the locations of the permitted and drilled (spudded) wells, property transactions, and the water service area. This map describes all wells and transactions in the sample, so some of the wells shown there were not present at the time of a nearby transaction. The large clustering of transactions in the center part of the county corresponds to the two cities in the county: Washington and Canonsburg. These cities fall along the major highway that cuts through the county (I-79, which connects with I-70 in Washington City). We hypothesize that properties within these major cities may face significant changes due to the economic boom associated with shale gas development. Thus, we exclude these cities in certain specifications in order to help isolate the disamenity value associated with proximity to a well from the property value benefits associated with the economic boom.

\footnotetext{
${ }^{17}$ Personal communication with the Development Manager at the Washington County Planning Commission, April 24, 2012.
} 


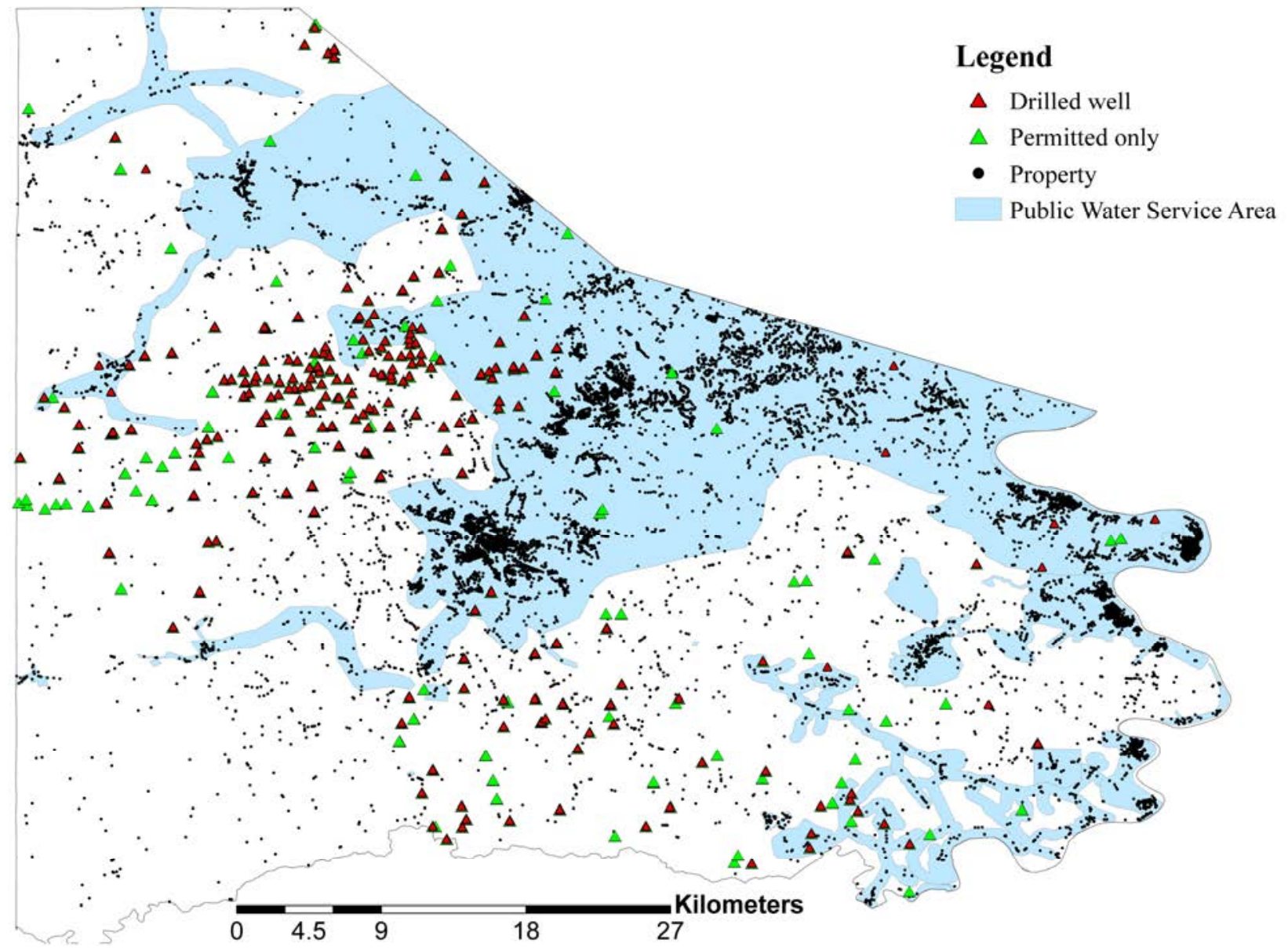

Figure 4: Property Sales in Washington County, 2004-2009. Includes Drilled Wells, Permitted Wells, and Public Water Service Areas 


\section{$6 \quad$ Results}

\subsection{Cross-Sectional Results}

We first report results for our cross-sectional specification, where we regress logged transaction prices on regression controls for property and census tract attributes, year dummies, and several treatment variables. These treatment variables include both inverse distance to the nearest drilled well and this variable interacted with a dummy for groundwater (which equals one if the property is located outside a PWSA). This allows us to separately identify the impact of proximity to a well for households living in groundwater areas. We expect this coefficient to be negative, as being closer to a well causes a greater risk to households living in groundwater areas. We also include inverse distance to the nearest permitted well in order to identify whether there is a different impact from permitted wells relative to drilled wells. This variable is also interacted with a groundwater dummy. We run the regression for the full sample as well as the subsample excluding the cities.

We find a positive and significant impact of proximity to a drilled well, though the interaction with groundwater is negative and insignificant. Inverse distance to a permitted well interacted with groundwater is positive but insignificant. The positive sign on the coefficient may be picking up the fact that proximity to a permitted well implies a likely lease payment. ${ }^{18}$ In fact, these lease payments increase with the amount of land leased, and lot sizes in groundwater areas are much larger than in the PWSA areas. Thus, the groundwater-dependent properties may positively capitalize on the permitting of the well before the negative amenities associated with drilling occur. However, given the insignificance of the coefficient on the interaction of groundwater with proximity, it is difficult to draw conclusions regarding the overall impact of proximity to wells for the groundwater area homes.

Since inverse distance is not a linear function of proximity, we cannot interpret

\footnotetext{
${ }^{18}$ Usually the mineral rights would be part of any property transfer, unless those rights were severed from the title to the property by being retained by the seller during the transfer, or sold to another party prior to the transfer. If mineral rights are sometimes severed, this would simply reduce the size of the price premium we estimate on well proximity. This should not, however, affect our estimates of the capitalization of groundwater contamination risk unless the probability of mineral right severance is correlated with water source in the area around the groundwater-PWSA boundary. We have no reason to suspect that this is the case.
} 
the magnitude of these coefficients directly. Instead, we take the derivative of the price with respect to distance (meters) in order to find the marginal effect of proximity on price. Thus, the derivative of the price function is:

$$
\partial(\ln p) / \partial(\text { distance })=-\beta /\left(\text { distance }^{2}\right)
$$

where $\beta$ is the coefficient and distance is in meters. For a PWSA property that is 1000 meters away from a well pad, the percent change in price from a one meter increase in distance is -0.03 percent $\left(-100 * 326.148 *\left(1 / 1000^{2}\right)\right)$, implying positive impacts on property values from proximity to wells (Table 3, column 1). The comparable result for groundwater-dependent properties is inconclusive given that the coefficient on the interaction term is insignificant. These results likely reflect the fact that the cross-sectional specification does not account for unobserved attributes of either the property or its location. These attributes may be correlated with proximity to a well and with water source, which can cause a bias in the cross-sectional coefficients. This leads us to employ a property fixed effects approach in order to remove these unobservable location attributes.

\subsection{Property Fixed Effect Results}

The signs of the coefficients from the FE specification are similar but larger and more significant than under the OLS specification. ${ }^{19}$ For the full sample (including cities), we find a positive impact of drilled shale gas well proximity on property values, though it is negative (and larger) for those households living in groundwater areas. This implies that shale development causes an increase in property values in general (perhaps due to lease payments, increased economic activity, or higher rental prices), though properties that do not have access to piped water have an overall negative impact due to shale gas development risks. When we exclude the cities, this effect is even more pronounced: the size of the coefficient on proximity to drilled wells decreases, suggesting that the effect of increased economic development is concentrated in the cities. The results imply that the marginal change in property values from moving one meter farther from

\footnotetext{
${ }^{19}$ There are more observations in columns 2 and 4 relative to columns 1 and 3 because of missing values for property characteristics-the fixed effects specification does not require these variables to be complete for all homes, so we are able to make use of more observations in the fixed effect regressions than in the OLS regressions.
} 
Table 3: Cross Sectional and Property Fixed Effects Estimates of the Effect of Shale Gas Wells on Log Sale Price

\begin{tabular}{|c|c|c|c|c|}
\hline & $\begin{array}{l}\text { (1) } \\
\text { OLS }\end{array}$ & $\begin{array}{l}(2) \\
\text { OLS }\end{array}$ & $\begin{array}{l}(3) \\
\mathrm{FE}\end{array}$ & $\begin{array}{l}(4) \\
\mathrm{FE}\end{array}$ \\
\hline Inverse Distance to Well $\left(\right.$ meters $\left.^{-1}\right)$ & $\begin{array}{l}326.148^{* * *} \\
(121.106)\end{array}$ & $\begin{array}{l}263.962^{* *} \\
(125.322)\end{array}$ & $\begin{array}{l}1103.470^{* *} \\
(447.170)\end{array}$ & $\begin{array}{l}764.502^{* *} \\
(363.109)\end{array}$ \\
\hline Inv. Dist. to Well*Groundwater & $\begin{array}{l}-290.933 \\
(207.612)\end{array}$ & $\begin{array}{l}-411.179 \\
(250.482)\end{array}$ & $\begin{array}{l}-1458.178^{* * *} \\
(420.039)\end{array}$ & $\begin{array}{l}-1351.901 * * * \\
(370.750)\end{array}$ \\
\hline Inv. Dist. to Permitted (not Drilled) Well & $\begin{array}{l}21.767 \\
(121.548)\end{array}$ & $\begin{array}{l}-151.561 \\
(225.927)\end{array}$ & $\begin{array}{l}296.562 \\
(335.141)\end{array}$ & $\begin{array}{l}1470.929 \\
(994.679)\end{array}$ \\
\hline Inv. Dist. to Permitted* Groundwater & $\begin{array}{l}193.943 \\
(228.639)\end{array}$ & $\begin{array}{l}605.057 \\
(406.166)\end{array}$ & $\begin{array}{l}-333.022 \\
(516.627)\end{array}$ & $\begin{array}{l}-1560.450 \\
(1213.657)\end{array}$ \\
\hline Groundwater & $\begin{array}{l}-.108 \\
(.069)\end{array}$ & $\begin{array}{l}-.098 \\
(.086)\end{array}$ & & \\
\hline Age & $\begin{array}{l}-.014^{* * *} \\
(.000)\end{array}$ & $\begin{array}{l}-.012^{* * *} \\
(.001)\end{array}$ & & \\
\hline Total Living Area (1000 sqft) & $\begin{array}{l}.283^{* * *} \\
(.019)\end{array}$ & $\begin{array}{l}.285^{* * *} \\
(.025)\end{array}$ & & \\
\hline No. Bathrooms & $\begin{array}{l}.070 * * * \\
(.021)\end{array}$ & $\begin{array}{l}.057^{*} \\
(.030)\end{array}$ & & \\
\hline No. Bedrooms & $\begin{array}{l}-.014 \\
(.018)\end{array}$ & $\begin{array}{l}-.026 \\
(.024)\end{array}$ & & \\
\hline Sold in Year Built & $\begin{array}{l}-.204^{* * *} \\
(.040)\end{array}$ & $\begin{array}{l}-.365^{* * *} \\
(.067)\end{array}$ & & \\
\hline Lot Size $(100,000$ sqft $)$ & $\begin{array}{l}.280 * * * \\
(.057)\end{array}$ & $\begin{array}{l}.301^{* * *} \\
(.064)\end{array}$ & & \\
\hline Lot Size Squared (100,000 sqft) & $\begin{array}{l}-.025^{*} \\
(.013)\end{array}$ & $\begin{array}{l}-.022^{* *} \\
(.010)\end{array}$ & & \\
\hline Distance to Nearest MSA $(\mathrm{km})$ & $\begin{array}{l}.011^{* * *} \\
(.002)\end{array}$ & $\begin{array}{l}.003 \\
(.003)\end{array}$ & & \\
\hline Mean Income (1000 dlls) & $\begin{array}{l}.005^{* * *} \\
(.001)\end{array}$ & $\begin{array}{l}.007^{* * *} \\
(.002)\end{array}$ & & \\
\hline$\%$ Unemployed & $\begin{array}{l}-.030^{* * *} \\
(.007)\end{array}$ & $\begin{array}{l}-.034^{* * *} \\
(.010)\end{array}$ & & \\
\hline$\%$ Age $25 \mathrm{w} /$ Bachelors & $\begin{array}{l}.027^{* * *} \\
(.004)\end{array}$ & $\begin{array}{l}.026^{* * *} \\
(.006)\end{array}$ & & \\
\hline \% Female Household Head & $\begin{array}{l}.006 \\
(.004)\end{array}$ & $\begin{array}{l}.009 \\
(.007)\end{array}$ & & \\
\hline \% Over 65 Years Old & $\begin{array}{l}.005^{*} \\
(.003)\end{array}$ & $\begin{array}{l}.014^{* *} \\
(.006)\end{array}$ & & \\
\hline$\%$ Black & $\begin{array}{l}-.007^{* *} \\
(.003)\end{array}$ & $\begin{array}{l}-.038^{* * *} \\
(.008)\end{array}$ & & \\
\hline$\%$ Hispanic & $\begin{array}{l}-.097^{* * *} \\
(.019)\end{array}$ & $\begin{array}{l}-.076^{* * *} \\
(.030)\end{array}$ & & \\
\hline 2006 & $\begin{array}{l}-.072^{*} \\
(.039)\end{array}$ & $\begin{array}{l}-.107^{*} \\
(.063)\end{array}$ & $\begin{array}{l}.345 \\
(.207)\end{array}$ & $\begin{array}{l}.325 \\
(.348)\end{array}$ \\
\hline 2007 & $\begin{array}{l}-.096^{* *} \\
(.040)\end{array}$ & $\begin{array}{l}-.076 \\
(.063)\end{array}$ & $\begin{array}{l}.704^{* * *} \\
(.197)\end{array}$ & $\begin{array}{l}.672^{* *} \\
(.325)\end{array}$ \\
\hline 2008 & $\begin{array}{l}-.248^{* * *} \\
(.042)\end{array}$ & $\begin{array}{l}-.259 * * * \\
(.065)\end{array}$ & $\begin{array}{l}.854^{* * *} \\
(.207)\end{array}$ & $\begin{array}{l}.859 * * * \\
(.321)\end{array}$ \\
\hline 2009 & $\begin{array}{l}-.493^{* * *} \\
(.059)\end{array}$ & $\begin{array}{l}-.525^{* * *} \\
(.084)\end{array}$ & $\begin{array}{l}1.394^{* * *} \\
(.265)\end{array}$ & $\begin{array}{l}1.498^{* * * *} \\
(.347)\end{array}$ \\
\hline $\begin{array}{l}\mathrm{n} \\
\text { Mean of Dep. Var. }\end{array}$ & $\begin{array}{l}10,833 \\
11.09107\end{array}$ & $\begin{array}{l}5,847 \\
10.94342\end{array}$ & $\begin{array}{l}10,960 \\
11.07652\end{array}$ & $\begin{array}{l}5,945 \\
10.92134\end{array}$ \\
\hline
\end{tabular}

Notes: Robust standard errors clustered at the census tract (102 census tracts). Columns (3) and (4) include property fixed effects. Columns (2) and (4) do not include the two largest cities in Washington County (Washington and Canonsburg). ${ }^{* * *}$ Statistically significant at the $1 \%$ level; ${ }^{* *} 5 \%$ level; ${ }^{*} 10 \%$ level. 
a well is - 0.0764 percent for PWSA properties and 0.059 percent $(0.076 \%-0.135 \%)$ for groundwater-dependent properties (Table 3, column 4) ${ }^{20}$ This presents some evidence that those living outside the PWSA, while attaining increased property values from lease payments, are not able to offset the negative impacts associated with groundwater risks.

According to Table 3, the relative effect of proximity to shale gas wells on groundwater and PWSA homes is very different in the OLS and fixed effects specifications. In the fixed effects specification, homes overall are more positively affected by proximity, although the effect on groundwater homes is more negative. We test the difference between the coefficients on proximity and proximity interacted with groundwater across the two specifications, and find that the interaction term changes significantly, although the proximity term alone does not. This demonstrates that there is an unobservable correlated with proximity and groundwater that is being picked up by the fixed effect approach. Specifically, the change in coefficients suggests that shale gas wells are being located near homes in groundwater areas that are unobservably better. There is indeed evidence that these groundwater area homes are observably better and have larger lots (See Table 5 for differences across homes located close to shale gas wells). Properties with larger lots - which tend to be located in groundwater areas - would be preferred by gas exploration and production companies, as leasing the same quantity of land would require fewer transactions and potentially lower costs per well. Though we control for lot size in the OLS specification, lot size may be correlated with positive unobservable attributes in groundwater areas, which would explain the shift in the interaction coefficient. However, as evidenced by Figure 1, there appear to be negative unobservables correlated with proximity in PWSA homes, which could drive the increase in the proximity coefficient when moving from OLS to fixed effects. ${ }^{21}$

Unfortunately, relying on fixed effects can be problematic given time varying

\footnotetext{
${ }^{20}$ The t-statistic on the difference in these parameters is -1.73 , implying a statistically significant net gain in property values from moving farther from the well.

${ }^{21}$ In order to create this figure we only included homes with one wellpad within 5000 meters, which excluded many of the groundwater dependent properties: the results from this figure are driven mostly by PWSA homes for which, given the upward sloping solid line, it would appear there are negative unobservables correlated with proximity. Creating a separate figure for groundwater and PWSA properties would have too few observations in each distance bin to be reliable. This does not affect our DDD estimation strategy, however, which relies on homes being located near one or more wells within 2000 meters.
} 
unobservables - e.g, the local economic boom and lease payments to individual homeowners. This warrants our use of a triple-difference estimator to remove these confounding effects.

\subsection{Difference-in-Difference-in-Differences}

Though we do not have information on gas lease payments to homeowners ${ }^{22}$ we assume that all properties (conditional upon proximity to a drilled well and other observables such as lot size) have an equal likelihood of receiving lease payments regardless of water service area. ${ }^{23}$ Moreover, while both may see their prices go up because of mineral rights and increased economic activity, properties that rely on groundwater may see their values increase by less (or even decrease) given concerns of groundwater contamination from nearby shale gas development. Our overlapping treatment and control groups based on well proximity and water source provide us with a two-part quasi-experiment with which we can tease out the negative impact of groundwater contamination from the positive impact of the mineral lease payments and economic activity.

We estimate the following regression equation:

$$
\log \left(\text { price }_{i t}=N_{2000, i t}+\text { Groundwater }_{i} * N_{2000, i t}+\theta_{t}+\mu_{i}+\nu_{i t}\right.
$$

where $N_{2000, i t}$ is a count of the number of well pads within 2000 meters at the time $t$ of sale. It equals zero if $t$ is before drilling takes place, or if property $i$ is more than 2000 meters from the nearest well pad. In addition, Groundwater is an indicator for whether property $i$ relies on groundwater; $\theta_{t}$ is a year fixed effect

\footnotetext{
${ }^{22}$ Mineral leases are filed at the county courthouse however not in an electronic format. Some leases have been scanned and are available in pdf format at www.landex.com, however, this service is geared towards viewing a handful of leases; downloading all leases in a county would be expensive and matching the leases to properties via an address or tax parcel number would likely be an imprecise endeavor.

${ }^{23}$ It could be the case that, given groundwater safety concerns, individuals in groundwater areas are less likely to sign a mineral lease, in which case we would overestimate the negative impact of a well in a groundwater area if fewer groundwater dependent homes are receiving lease payments. Our results would thus be interpreted as an upper bound on the negative impact of proximity for groundwater dependent homes. However, gas exploration and production companies will only drill after obtaining the mineral rights to a sufficiently large area to warrant drilling, implying that holdouts are the minority in areas where wells have been drilled. Furthermore, property owners unwilling to sign based on groundwater contamination concerns are likely rare; if others nearby have granted their mineral rights, groundwater contamination is not prevented by not signing.
} 
to capture trends over time; $\mu_{i}$ is a property fixed effect that absorbs the timeinvariant differences between properties that eventually have one or more wells within 2000 meters and those that do not, ${ }^{24}$ as well as time-invariant differences between groundwater and PWSA properties. The interaction Groundwater $_{i} *$ $N_{2000, i t}$ measures the treatment effect on groundwater homes relative to PWSA homes, accounting for any time-varying unobservables that similarly affect close and distant properties.

Finally, in order to reduce the burden on our differencing strategy to control for time-varying unobserved neighborhood attributes, our main specification only looks at properties located within 1000 meters of either side of the border of the PWSA. ${ }^{25}$ This represents the smallest (and most homogenous) geographic area we can use that still contains properties relying on groundwater along with properties in the PWSA.

In order to validate our assumption of common time trends across the two groups (PWSA and groundwater) and within the same neighborhood (1000 meters from the border), we regress transaction values on the property characteristics and census tract attributes that are used in our cross-sectional specification, and then calculate the residuals, separately for groundwater-dependent and PWSA homes. We plot the residuals over time prior to any wells being drilled (the first well in Washington County was drilled in June 2005), once for a restricted sample of homes located within 1000 meters of either side of the PWSA border, and once for the entire sample of homes in Washington County. Figure 5 plots the time trend across the full sample of the two groups, while Figure 6 restricts the sample to homes located within 1000 meters of either side of the PWSA border. Both figures track quite well across the two samples prior to any property being treated by a well, although the restricted sample (which is our final DDD sample) tracks more closely. This demonstrates that focusing on homes that are closer together helps eliminate differing pre-trends across the control and treatment group, thereby validating our DDD approach with the restricted sample.

\footnotetext{
${ }^{24}$ While being located inside the PWSA or groundwater area may not be invariant over time, we only have data on the most recent layout of the PWSA; thus our data on water service are time invariant and we do not include a groundwater dummy in this specification.

${ }^{25} \mathrm{We}$ also include a specification with the entire sample in Washington County to test how the assumption of common trends changes with a larger group.
} 


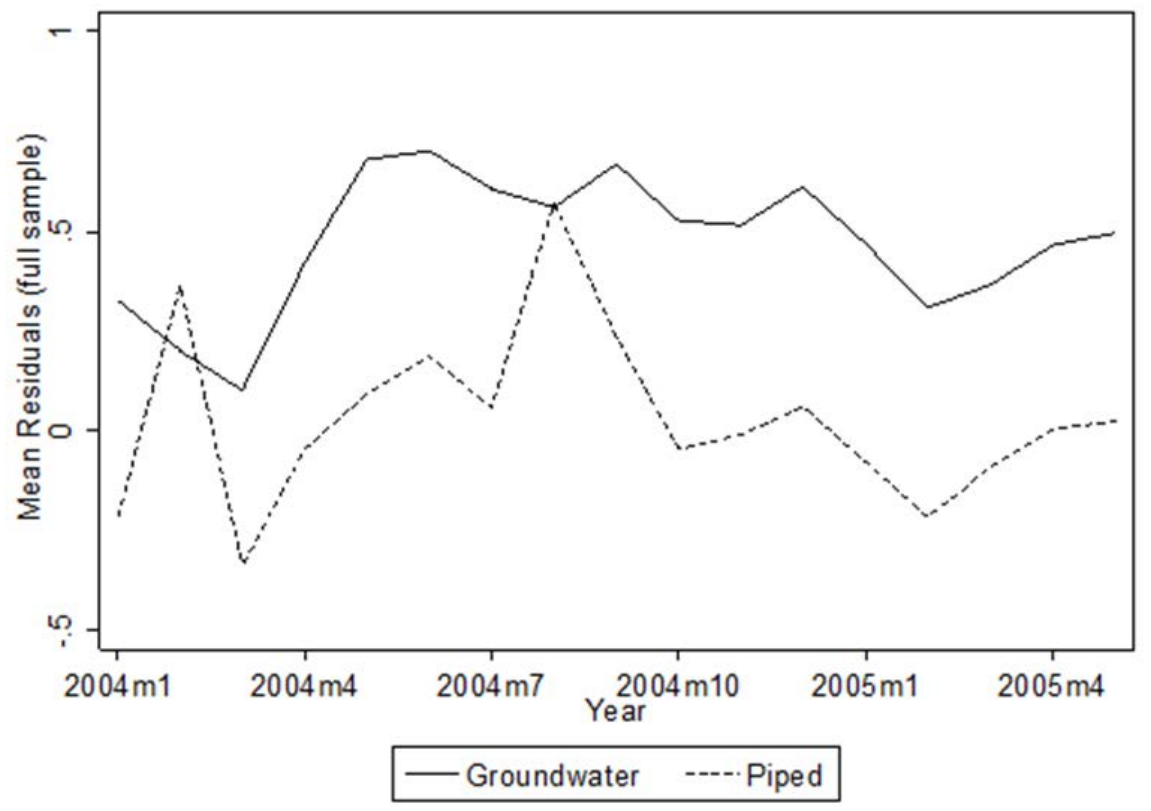

Figure 5: Mean Residuals of Log Transaction Price using the Full Sample

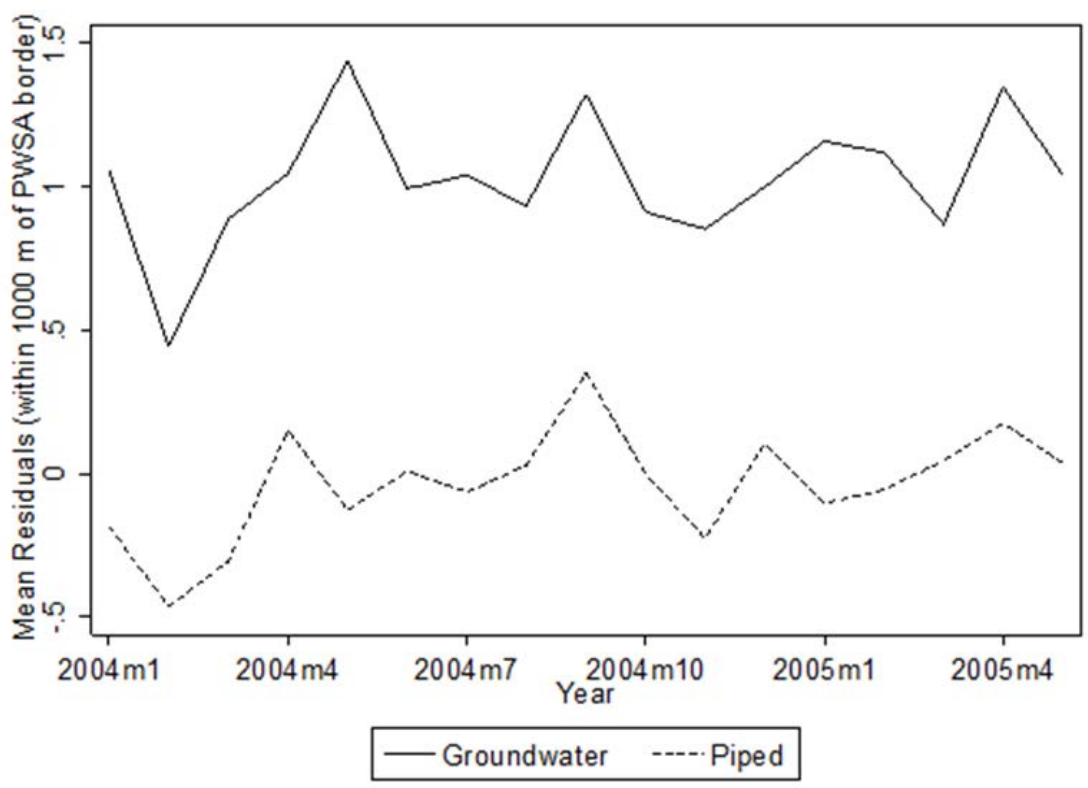

Figure 6: Mean Residuals of Log Transaction Price using the properties located $1000 \mathrm{~m}$ from the PWSA Border 
We provide additional evidence to validate our assumption that PWSA homes within 1000 meters of the PWSA border are a good control for the groundwaterdependent homes near the other side of the border, by inspecting aerial maps of the homes in this region. We find that, for nearly all of our sample, PWSA and groundwater areas are not divided in such a way as might cause neighborhood discontinuity (e.g., such as by a highway, railroad track, etc). ${ }^{26}$ This provides further justification for use of homes on the PWSA side of the border as controls for the groundwater-dependent homes in our DDD method.

We estimate our DDD specification using a number of different subsamples. In our first two regressions, we use a subsample that omits properties that were sold after they had permitted (but not yet drilled) wells within 2000 meters (columns 1 and 2 of Table 4). This subsample removes properties that may be receiving lease or bonus payments from a gas exploration and development company due to a permitted but not drilled well. The initial specification in column 1 looks at all properties in both the PWSA and groundwater areas (instead of only those located along the PWSA border), which allows us to test the importance of the assumption of common time trends close to the border. In the second regression (column 2) we restrict the sample to PWSA border homes. Since it is possible that the PWSA has been extended beyond the border designated in our data, we omit properties that are 300 meters on the groundwater side of a water service area in order to reduce the risk of including misclassified properties. Our third specification looks at all properties in Washington county, including the properties with permitted (but undrilled) wells, but controls for these with an indicator for having permitted wells nearby, as well as the interaction of this indicator with Groundwater (column 3). ${ }^{27}$. Finally, this third specification is also run using only the PWSA border home properties (column 4). Thus, only columns 2 and 4 allow for the assumption of common time trends.

\footnotetext{
${ }^{26}$ One exception is displayed in the Appendix (Figure 9), where highway I-70 coincides with the PWSA boundary. Our results are robust to dropping homes located in this area.

${ }^{27}$ Including properties treated by permitted wells increases the sample size by 128 observations for the full sample, and by 46 for the band around the PWSA border.
} 
Table 4: DDD Estimates of the Effect of Shale Gas Wells on Log Sale Price by Drinking Water Source

\begin{tabular}{lllll}
\hline & $(1)$ & $(2)$ & $(3)$ & $(4)$ \\
& Full & Band & Full & Band \\
\hline Wellpads Drilled within 2km & $.288^{* * *}$ & $.321^{* * *}$ & $.091^{*}$ & $.107^{* *}$ \\
& $(.068)$ & $(.082)$ & $(.053)$ & $(.040)$ \\
Wellpads Drilled within 2km*Groundwater & $-.901^{* *}$ & $-.433^{* * *}$ & .011 & $-.236^{*}$ \\
& $(.370)$ & $(.117)$ & $(.106)$ & $(.124)$ \\
Wellpads Permitted (not drilled) within 2km & & & .177 & -.036 \\
& & & $(.119)$ & $(.088)$ \\
Wellpads Permitted (not drilled) within $2 \mathrm{~km}^{*}$ Groundwater & & & .002 & -.749 \\
& & & $(.123)$ & $(.593)$ \\
Year Effects & & & Yes & Yes \\
Property Effects & Yes & Yes & Yes & Yes \\
\hline $\mathrm{n}$ & 17,779 & 3,229 & 17,907 & 3,275 \\
\hline
\end{tabular}

Notes: Robust standard errors clustered at the census tract (102 census tracts). All specifications include year-of-sale and property fixed effects. Columns (1) and (2) are specifications that omit properties with wells permitted (but not drilled) within 2000 meters. Columns (3) and (4) include properties with wells permitted within 2000 meters. Columns (2) and (4) only examine properties within a 1000 meter band around the water service area. ${ }^{* * *}$ Statistically significant at the $1 \%$ level; $* * 5 \%$ level; $* 10 \%$ level.

Similar to the cross-sectional and FE results, we find that property values go up after a well pad has been drilled within 2000 meters, while properties that rely on groundwater are negatively affected by exposure. We find that permitted (but not drilled) wells do not have a significant effect on property values in our final specification, though controlling for these wells reduces the impacts (both positive and negative) of the treatment on property values relative to column 2 (Table 4, column 4). Though insignificant, the parameter estimate on the interaction term of permitted wells with the groundwater indicator is large and negative, providing some evidence that permitting may be negatively capitalized into the property value by groundwater homes. This could be due to the fact that the new home buyer is aware of the forthcoming drilling activity due to incoming lease payments or that construction has already begun to occur nearby.

The estimates in the final specification (column 4) demonstrate that properties in the PWSA positively capitalize proximity to a well pad by 10.7 percent, and this result is statistically significant. This is most likely due to lease payments, which allow properties in the PWSA to increase their values while avoiding the risks (or perceived risks) of contaminated groundwater. For properties that depend on groundwater, however, the estimate of the effect of drilling a well pad 
within 2000 meters implies a decrease in property values of 23.6 percent. The net impact of these two effects is made up of a statistically significant reduction in value of 23.6 percent attributable to groundwater contamination risk, partially offset by the 10.7 percent increase (likely) attributable to lease payments. Their difference (-12.9 percent) while not itself significant ${ }^{28}$ suggests that, in contrast to PWSA homes, prices of groundwater dependent properties certainly do not rise as a result of nearby drilling, and may fall because of groundwater contamination risk.

The final estimation also demonstrates the importance of controlling for the fact that gas exploration and development companies have strategic location decisions. In the third specification, permitted wells significantly decrease values for groundwater dependent homes, though this significance disappears when we only look at homes near the PWSA border. Since gas wells near both sides of the border are located in relatively similar areas, they are less likely to be located in strategically different ways, and hence our final specification demonstrates that not controlling for these location decisions can cause groundwater dependent homes to appear more harmed by proximity to wells than they truly are.

\section{Conclusion}

Our study seeks to understand and quantify the positive and negative impacts of shale gas development on nearby property values. Our goal is to distinguish who benefits and who loses from this unconventional form of natural gas extraction. Specifically, we focus on the potential for groundwater contamination, one of the most high-profile risks associated with drilling. We demonstrate that those risks lead to a large and significant reduction in property values. These reductions offset any gains to the owners of groundwater-dependent properties from lease payments or improved local economic conditions, and may even lead to a net drop in prices. Unfortunately, due to limitations on lease payment data, we are not able to disentangle the positive effects of nearby drilling on property values from the effects of negative externalities that are not associated with groundwater risks (e.g., increased traffic; noise, air, and light pollution) - doing so is the subject of ongoing research. With our triple-difference strategy, we are, however,

\footnotetext{
${ }^{28}$ The t-statistic on the difference in these parameters is -1.03 .
} 
able to provide evidence that concern for groundwater contamination risk significantly decreases the value of nearby homes. Thus, being able to mitigate the potential for water contamination from shale gas development (such as through the extension of the piped water service area) allows properties to benefit from the lease payments and increased economic activity that accompanies drilling without having to bear the cost of the groundwater risks. This finding also provides added impetus for regulators to increase regulations to protect groundwater around hydraulic fracturing sites and for industry to increase transparency and voluntary action to reduce water contamination concerns.

To the extent that the net effect of drilling on groundwater-dependent properties might even be negative, we could see an increase in the likelihood of foreclosure in areas experiencing rapid growth of hydraulic fracturing. The U.S. government acknowledged the possible negative consequences of allowing leasing on mortgaged land in March 2012 when it began discussing a regulation requiring an environmental review of any property with an oil and gas lease before issuing a mortgage. ${ }^{29}$ However, this proposed regulation was rejected within a week. ${ }^{30}$ The overall lack of research regarding the impacts on property values from proximity to shale gas wells hinders the ability of the government to regulate optimally, both at the national and local levels. This paper helps to fill that void.

\footnotetext{
29"Mortgages for Drilling Properties May Face Hurdle," New York Times, 18 March 2012.

30"U.S. Rejects Environmental Reviews on Mortgages Linked to Drilling," New York Times, 23 March 2012.
} 


\section{References}

T.J. Bartik. Measuring the benefits of amenity improvements in hedonic price models. Land Economics, 64(2):172-183, 1988.

P.C. Boxall, W.H. Chan, and M.L. McMillan. The impact of oil and natural gas facilities on rural residential property values: a spatial hedonic analysis. Resource and Energy Economics, 27(3):248-269, 2005.

L.W. Davis. The effect of power plants on local housing values and rents. Review of Economics and Statistics, 93(4):1391-1402, 2011.

EPA. EPA Releases Draft Findings of Pavillion, Wyoming Ground Water Investigation for Public Comment and Independent Scientific Review, Environmental Protection Agency News Release . 2011. URL http://yosemite.epa.gov/opa/admpress.nsf/ O/EF35BD26A80D6CE3852579600065C94E.

D. Guignet. What do property values really tell us? a hedonic study of underground storage tanks. NCEE Working Paper Series, 2012.

M.D. Heintzelman and C.M. Tuttle. Values in the Wind: A Hedonic Analysis of Wind Power Facilities. Land Economics, 88(3):571-588, 2012.

K. Hirano and G.W. Imbens. The propensity score with continuous treatments. Applied Bayesian Modeling and Causal Inference from Incomplete-Data Perspectives, pages 73-84, 2004.

H. Allen Klaiber and Sathya Gopalakrishnan. The Impact of Shale Exploration on Housing Values in Pennsylvania, Working Paper. 2012.

Nicolai V. Kuminoff and Jaren Pope. Do "Capitalization Effects" for Public Goods Reveal the Public's Willingness to Pay? Working Paper. 2012.

L. Linden and J.E. Rockoff. Estimates of the impact of crime risk on property values from megan's laws. The American Economic Review, 98(3):1103-1127, 2008.

J. Marchand. Local labor market impacts of energy boom-bust-boom in western canada. Journal of Urban Economics, 2011.

T. Myers. Potential contaminant pathways from hydraulically fractured shale to aquifers. Ground Water, 2012.

New York State Department of Environmental Conservation. Revised Draft Supplemental Generic Environmental Impact Statement On The Oil, Gas and Solution Mining Regulatory Program, Well Permit Issuance for Horizontal Drilling and High-Volume Hydraulic Fracturing to Develop the Marcellus Shale and Other Low-Permeability Gas Reservoirs. 2011. URL http://www.dec.ny.gov/docs/materials_minerals_ pdf/rdsgeisexecsum0911.pdf. 
Stephen G. Osborn, Avner Vengosh, Nathaniel R. Warner, and Robert B. Jackson. Methane contamination of drinking water accompanying gas-well drilling and hydraulic fracturing. Proceedings of the National Academy of Sciences, 108(20):81728176, 2011.

RB Palmquist, FM Roka, and T. Vukina. Hog operations, environmental effects, and residential property values. Land Economics, 73(1):114-124, 1997.

S. Rosen. Hedonic prices and implicit markets: product differentiation in pure competition. The Journal of Political Economy, 82(1):34-55, 1974.

SEAB. Shale Gas Production Subcommittee Second Ninety Day Report, Secretary of Energy Advisory Board,U.S. Department of Energy. November 2011.

B.R. Swistock, W.E. Sharpe, and P.D. Robillard. A survey of lead, nitrate and radon contamination of private individual water systems in Pennsylvania. Journal of Environmental Health, 55(5):6-12, 1993.

N.R. Warner, R.B. Jackson, T.H. Darrah, S.G. Osborn, A. Down, K. Zhao, A. White, and A. Vengosh. Geochemical evidence for possible natural migration of Marcellus formation brine to shallow aquifers in Pennsylvania. Proceedings of the National Academy of Sciences, 109(30):11961-11966, 2012.

J.G. Weber. The effects of a natural gas boom on employment and income in Colorado, Texas, and Wyoming. Energy Economics, 2011. 


\section{A Appendix}

Table 5: Means (and Standard Deviations) of Property Characteristics by Distance to Nearest Current or Future Well

\begin{tabular}{|c|c|c|c|c|}
\hline & $<2 \mathrm{~km}$ & $2-4 \mathrm{~km}$ & $4-6 \mathrm{~km}$ & $6-8 \mathrm{~km}$ \\
\hline Transaction Price (Dollars) & $\begin{array}{l}120,108 \\
(107,633)\end{array}$ & $\begin{array}{l}112,262 \\
(103,219)\end{array}$ & $\begin{array}{l}104,810 \\
(116,334)\end{array}$ & $\begin{array}{l}104,300 \\
(97,693)\end{array}$ \\
\hline Age & $\begin{array}{l}54.58 \\
(39.19)\end{array}$ & $\begin{array}{l}54.65 \\
(40.3)\end{array}$ & $\begin{array}{l}57.62 \\
(40.01)\end{array}$ & $\begin{array}{l}58.66 \\
(40.17)\end{array}$ \\
\hline Total Living Area (1000 sqft) & $\begin{array}{l}1.896 \\
(1.004)\end{array}$ & $\begin{array}{l}1.747 \\
(.8265)\end{array}$ & $\begin{array}{l}1.642 \\
(.679)\end{array}$ & $\begin{array}{l}1.682 \\
(.7133)\end{array}$ \\
\hline No. Bathrooms & $\begin{array}{l}1.612 \\
(.9343)\end{array}$ & $\begin{array}{l}1.48 \\
(.9562)\end{array}$ & $\begin{array}{l}1.482 \\
(.9373)\end{array}$ & $\begin{array}{l}1.521 \\
(.931)\end{array}$ \\
\hline No. Bedrooms & $\begin{array}{l}2.699 \\
(1.067)\end{array}$ & $\begin{array}{l}2.52 \\
(1.21)\end{array}$ & $\begin{array}{l}2.452 \\
(1.164)\end{array}$ & $\begin{array}{l}2.577 \\
(1.151)\end{array}$ \\
\hline Sold in Year Built & $\begin{array}{l}.06311 \\
(.2437)\end{array}$ & $\begin{array}{l}.1222 \\
(.3278)\end{array}$ & $\begin{array}{l}.1013 \\
(.3019)\end{array}$ & $\begin{array}{l}.1162 \\
(.3206)\end{array}$ \\
\hline Lot Size $(100,000 \mathrm{sqft})$ & $\begin{array}{l}.4076 \\
(.5176)\end{array}$ & $\begin{array}{l}.2238 \\
(.3906)\end{array}$ & $\begin{array}{l}.2209 \\
(.4955)\end{array}$ & $\begin{array}{l}.1864 \\
(.3763)\end{array}$ \\
\hline Distance to Nearest MSA (km) & $\begin{array}{l}34.81 \\
(5.76)\end{array}$ & $\begin{array}{l}34.99 \\
(6.184)\end{array}$ & $\begin{array}{l}35.74 \\
(7.013)\end{array}$ & $\begin{array}{l}37.77 \\
(5.631)\end{array}$ \\
\hline Mean Income & $\begin{array}{l}68,851 \\
(11,678)\end{array}$ & $\begin{array}{l}59,431 \\
(12,038)\end{array}$ & $\begin{array}{l}59,431 \\
(12,749)\end{array}$ & $\begin{array}{l}58,681 \\
(16,620)\end{array}$ \\
\hline \% Under 19 Years Old & $\begin{array}{l}24.67 \\
(4.066)\end{array}$ & $\begin{array}{l}23.66 \\
(4.523)\end{array}$ & $\begin{array}{l}23.01 \\
(3.095)\end{array}$ & $\begin{array}{l}23.67 \\
(4.566)\end{array}$ \\
\hline$\%$ Black & $\begin{array}{l}1.846 \\
(3.082)\end{array}$ & $\begin{array}{l}4.277 \\
(4.529)\end{array}$ & $\begin{array}{l}3.393 \\
(3.62)\end{array}$ & $\begin{array}{l}5.518 \\
(7.88)\end{array}$ \\
\hline$\%$ Hispanic & $\begin{array}{l}.6519 \\
(.9262)\end{array}$ & $\begin{array}{l}.681 \\
(1.026)\end{array}$ & $\begin{array}{l}.2979 \\
(.4401)\end{array}$ & $\begin{array}{l}.4773 \\
(.7651)\end{array}$ \\
\hline$\%$ Age 25 w/High School & $\begin{array}{l}43.52 \\
(4.766)\end{array}$ & $\begin{array}{l}43 \\
(5.573)\end{array}$ & $\begin{array}{l}41.26 \\
(7.712)\end{array}$ & $\begin{array}{l}41.82 \\
(7.977)\end{array}$ \\
\hline$\%$ Age 25 w Bachelors & $\begin{array}{l}13.98 \\
(3.421)\end{array}$ & $\begin{array}{l}14.03 \\
(3.838)\end{array}$ & $\begin{array}{l}14.98 \\
(5.9)\end{array}$ & $\begin{array}{l}14.83 \\
(6.393)\end{array}$ \\
\hline$\%$ Same House 1 Year & $\begin{array}{l}89.99 \\
(3.055)\end{array}$ & $\begin{array}{l}88.81 \\
(3.96)\end{array}$ & $\begin{array}{l}87.99 \\
(4.838)\end{array}$ & $\begin{array}{l}87.02 \\
(7.504)\end{array}$ \\
\hline \% Unemployed & $\begin{array}{l}6.243 \\
(1.648)\end{array}$ & $\begin{array}{l}7.028 \\
(2.269)\end{array}$ & $\begin{array}{l}5.979 \\
(2.46)\end{array}$ & $\begin{array}{l}6.859 \\
(3.09)\end{array}$ \\
\hline$\%$ Poverty & $\begin{array}{l}4.764 \\
(3.366)\end{array}$ & $\begin{array}{l}6.286 \\
(4.513)\end{array}$ & $\begin{array}{l}7.019 \\
(4.633)\end{array}$ & $\begin{array}{l}8.53 \\
(7.882)\end{array}$ \\
\hline \% Public Assistance & $\begin{array}{l}1.991 \\
(1.025)\end{array}$ & $\begin{array}{l}1.962 \\
(1.574)\end{array}$ & $\begin{array}{l}2.126 \\
(1.763)\end{array}$ & $\begin{array}{l}2.526 \\
(2.576)\end{array}$ \\
\hline \% Over 65 Years Old & $\begin{array}{l}17.3 \\
(3.711)\end{array}$ & $\begin{array}{l}18.13 \\
(4.46)\end{array}$ & $\begin{array}{l}18.08 \\
(4.674)\end{array}$ & $\begin{array}{l}17.67 \\
(5.233)\end{array}$ \\
\hline$\%$ Female Household Head & $\begin{array}{l}9.577 \\
(3.349)\end{array}$ & $\begin{array}{l}11.62 \\
(4.727)\end{array}$ & $\begin{array}{l}10.59 \\
(4.205)\end{array}$ & $\begin{array}{l}12.19 \\
(5.438)\end{array}$ \\
\hline Ground Water & $\begin{array}{l}.4396 \\
(.4975)\end{array}$ & $\begin{array}{l}.1639 \\
(.3704)\end{array}$ & $\begin{array}{l}.09304 \\
(.2906)\end{array}$ & $\begin{array}{l}.06808 \\
(.2519)\end{array}$ \\
\hline Observations & 207 & 775 & 1623 & 2130 \\
\hline
\end{tabular}

Notes: Summary statistics based on the distance to the closest well drilled at time of sale or at some time in the future. 


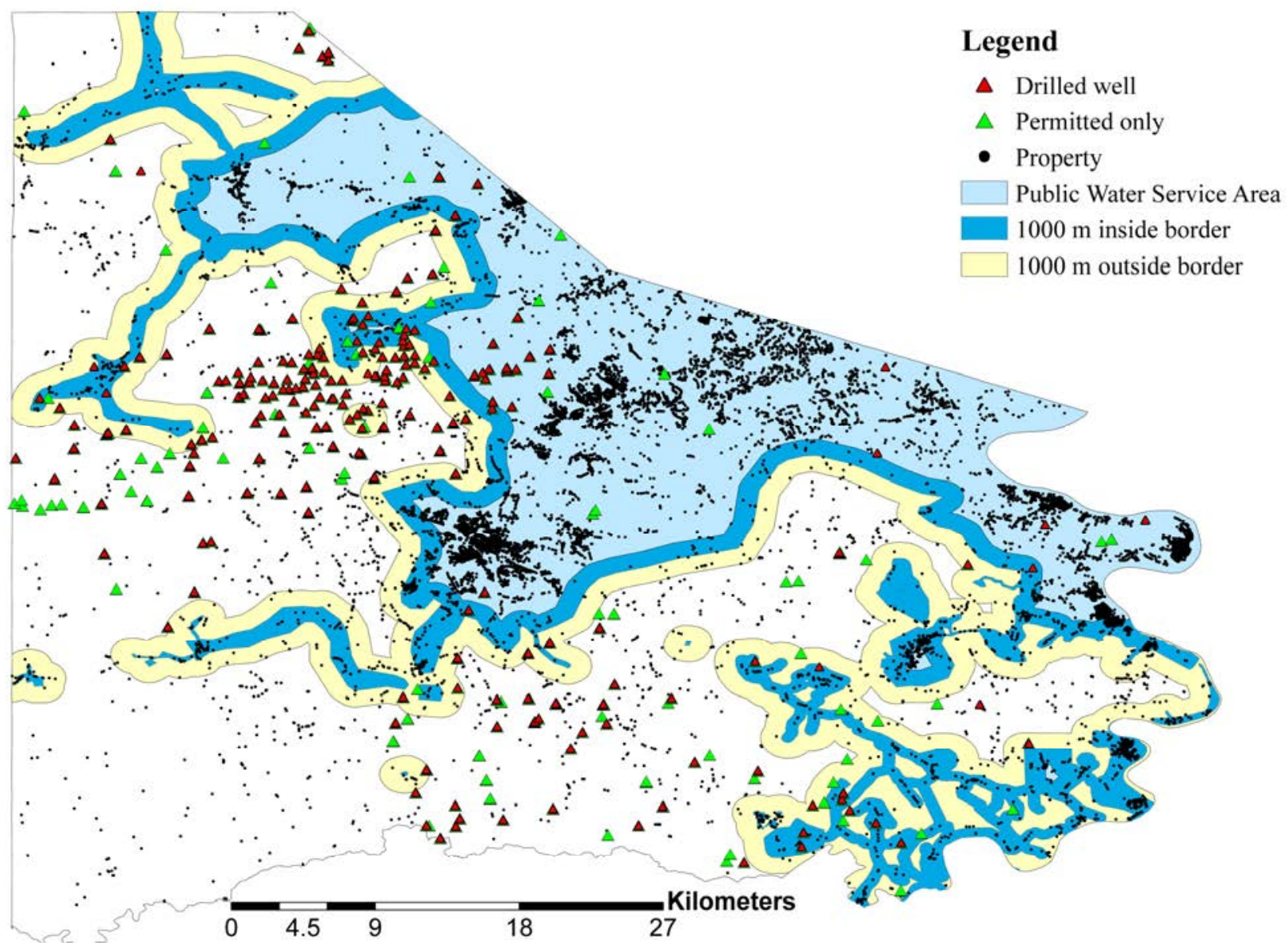

Figure 7: Property Sales and permitted and drilled wells in Washington County, 2004-2009. Indicates 1000 meter band inside and outside of Public Water Service Areas. 


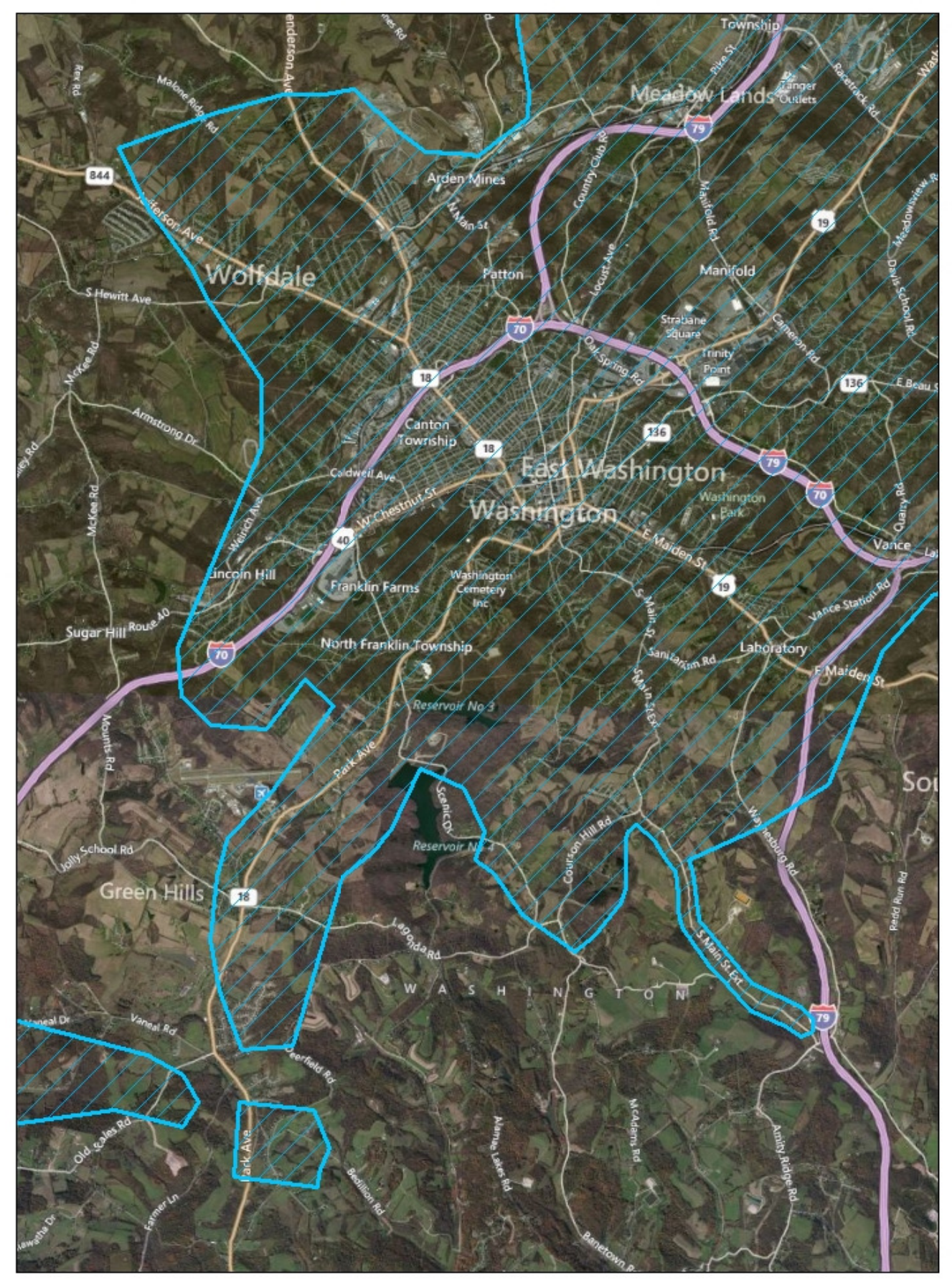

Figure 8: Example of no artificial boundaries: Close-up of Washington City. 


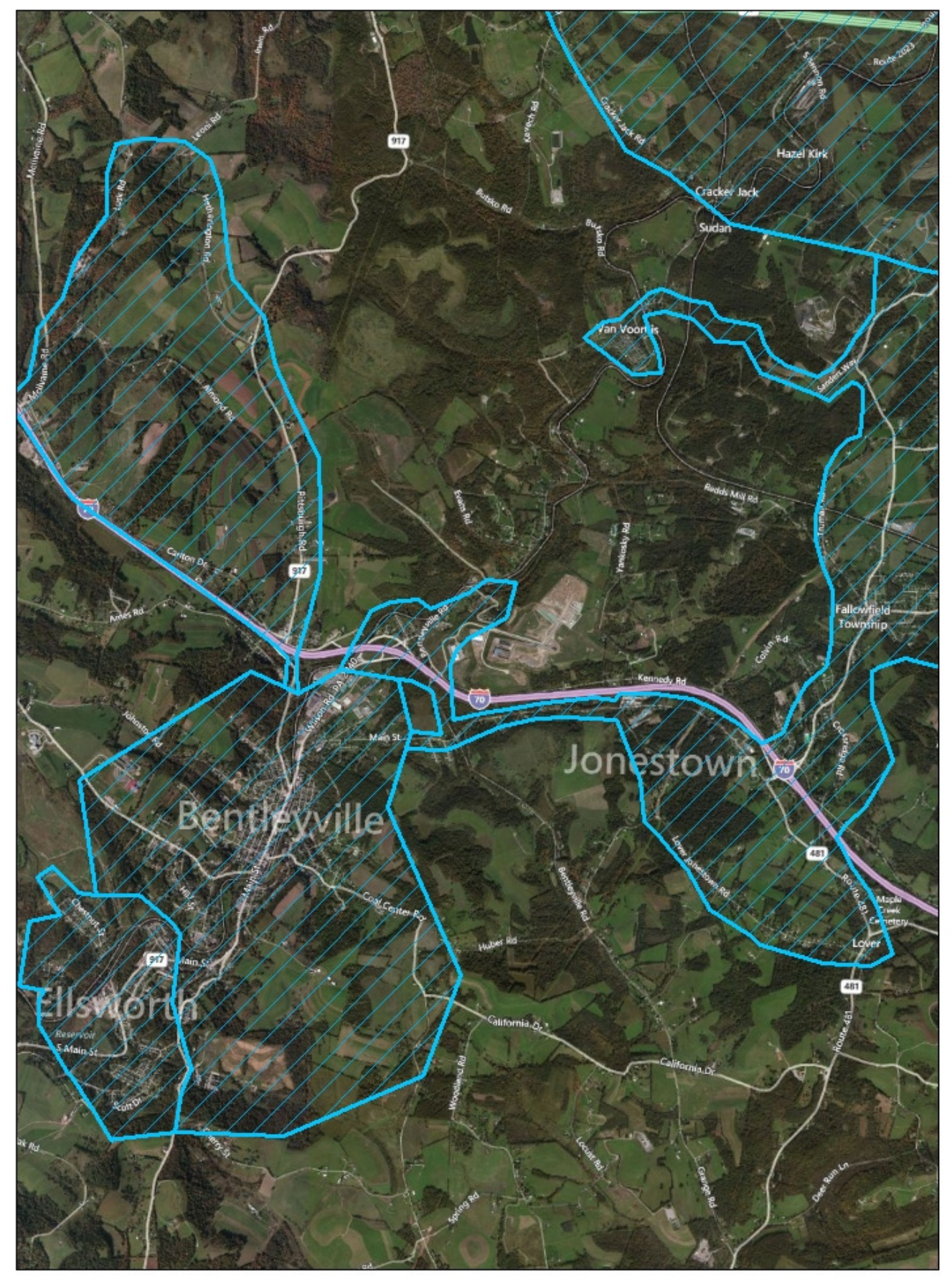

Figure 9: One exception where a highway coincides with the PWSA boundary; Our results are robust to dropping this area. 